\title{
ISLAMIC BUSINESS COACHING FROM THE PERSPECTIVE OF INDONESIAN COACHES
}

\author{
Muhammad Sholahuddin ${ }^{1}$ \\ Kulliyyah of Economics \& Management Sciences, \\ International Islamic University of Malaysia (IIUM), Malaysia \\ Faculty of Economics \& Business, Universitas Muhammadiyah Surakarta, Indonesia \\ (Email: Muhammad.sholahuddin@ums.ac.id) \\ Moha Asri Abdullah ${ }^{2}$ \\ Kulliyyah of Economics \& Management Sciences, \\ International Islamic University of Malaysia (IIUM) \\ (Email: mosri@iium.edu.my) \\ Mohd. Nizam Barom ${ }^{3}$ \\ Kulliyyah of Economics \& Management Sciences, \\ International Islamic University of Malaysia (IIUM) \\ (Email: mohdnizam@iium.edu.my) \\ Ibrahim Nuhu Tahir ${ }^{4}$ \\ Kulliyyah of Economics \& Management Sciences, \\ International Islamic University of Malaysia (IIUM) \\ (Email: ibrahimnuhu@iium.edu.my)
}

Accepted date: $30-06-2019$

Published date: 10-07-2019

To cite this document: Sholahuddin, M., Abdullah, M. A., Barom, M. N., \& Tahir, I. N. (2019). Islamic Business Coaching From The Perspective of Indonesian Coaches. International Journal of Modern Trends in Social Sciences, 2(8), 174-187.

DOI: $10.35631 /$ IJMTSS.280017

\begin{abstract}
In an increasingly competitive era of trade, training is insufficient to help solve business problems and challenges that often change daily. Meanwhile, business professionals realize that the coaching process used for the past dozen years by athletes, orators, and artists to improve their performance can also be used to help entrepreneurs to help accelerate business goals and personal success. Organizations that offer coaching have grown rapidly over the past decade. Even though in Indonesia, several coaching Islamic businesses have their communities, until now there is limited literature on Islamic business coaching. This study develops definitions for Islamic business coaching along with its characteristics for the Indonesian setting. This was achieved using qualitative research. Data were collected with interviewing 5 Islamic Indonesian master coaches. Recording of interviews was transcribed and coded. Then, those were analyzed with content analysis. The paper concludes that Islamic business coaching differs from conventional coaching due to being based on Islamic religiosity and principles. In Addition, the characteristics of Islamic business coaching include Islamic business coach's role, Islamic business coaching session focus, and Islamic business coaching results.
\end{abstract}

Keywords: Islamic Business Coaching, Training, Mentoring, Small Business, Coach 


\section{Introduction}

It has been generally recognised that business coaching plays a vital role in developing small businesses. Although it is still an emerging area in human and organisational development (Whiteside, 2013), its role in the start-up of small businesses is increasingly recognised (Audet \& Couteret, 2012) and is expected to increase performance and help expand businesses. However, many have emphasised the inability of existing training method in dealing with the ever dynamic issues and challenges faced by entrepreneurs at a daily basis (Bennis \& O'Toole, 2005). Entrepreneurial leaders need day-to-day attention because of changing business situations, but education and training received do not seem able to meet that challenge (Swanson \& Holton, 1997). For this reason, there is increasing attention on business coaching practised especially among small businesses as they are exposed to a highly challenging and competitive market environment. Business coaching is coaching, which focuses on how to maximise empowering the client's potency to increase the performance of the client's business.

The existing business environment presents many difficulties for Muslim entrepreneurs to be consistent with their religious principles in doing business, such as avoiding interest or usury and the absence of values in the market environment. Here lies the importance of Islamic Business Coaching (IBC), which is not only making businesses thrive with modern knowledge but does so according to Islamic values and principles. Islamic business coaching (IBC) is business coaching in Islamic principle. Muslim entrepreneurs should follow the IBC programme so that they can have professional modern business management while understanding Islamic economic jurisprudence, avoiding improper transactions, and inappropriate religious and spiritual values (Arifin, 2015).

Many studies have recognised the importance of incorporating Islamic values and principles in the practice of business coaching. The importance of Islamic coaching has been acknowledged (Grine, 2014; Habib, 2012). Habib (2012) described how to create one's life vision, set goals, and have life-skills such as time management and financial management, and build self-esteem through a merging of daily practical advice, toolkits for changing one's life, diagnostic exercises and spiritual wisdom led by selected verses from the Holy Qur'an and sayings of Prophet Muhammad (PBUH). Grine (2014) studied the use of executive coaching and mentoring to empower. Social and institutional development is influenced based on the quality of Muslim women concerning self-development. Despite such efforts, there is a lack of evidence about Islamic business coaching, especially in Indonesia. Indonesia has the biggest Muslim population globally. Thus, this study examines the Islamic business coaching from the perspective of Indonesian coaches.

(TNR, 12, single spacing, justify)

\section{Literature}

\section{Religion and Spirituality in Business Coaching}

Islam is not only a religion instructing to pray, worship and do some rituals, but also a way of life concerning every aspect of the existence of individuals, groups and societies. As a part of its goals, Islam regards developing human beings as one of its supreme moral values (Hassi, 2012). Earning a living by doing halal jobs (lawful and permissible) is an important part of one's role as a Muslim. 
Although Dana (2009) argues that Islam constrains entrepreneurship because of the prohibition of interest that also represents a barrier to capital, Prophet Muhammad (P.B.U.H) and some of his companions were successful entrepreneurs with Islamic business ethics, including using interest-free capital. Thus, Islam is not merely a religion but also spirituality and a way of life from God.

To be good at work, knowledge ( $\mathrm{ilm}$ ) is an important requirement. In this regard, Islam gives high status to seeking knowledge as stated by Prophet Muhammad (PBUH) in Sunan Ibn Maja (Fatoohi, 2009): "Looking for knowledge is an obligation laid on every Muslim." Additionally, individuals are expected to "seek knowledge from the cradle to the grave," as suggested by the Prophet (Fatoohi, 2009). Learning is a never-ending process that also includes various coaching, training, and other educational activities based on Islamic guidelines - as occurred at Dar Al Arqam during the Prophet's lifetime. There is little doubt if any education constitutes the lifeline of any society. It transmits values and the legacy of a given society from one generation to another generation (Hashim, 2010).

Allah says in the Holy Quran, "O my Lord! Increase me in knowledge" (20:144). Similarly, Muhammad (P.B.U.H) said, "He whom death overtakes while he is engaged in seeking knowledge with a view to reviving Islam with the help of it, there will be only one degree between him and the Prophets in Paradise". Since that, Islam rates education highly.

Within the Islamic perspective on education, there are three primary dimensions: tarbiyah, which means to encourage growth; $t a$ 'dib, which signifies discipline; and ta'lim, which means to instruct (Halstead, 2004). In its essence, education in Islam aims to nurture human beings, deals with individual development, moral gaining and training, and pursuit of knowledge. The system of education in Islam aims to teach learners about knowledge related to the world and hereafter and to assist them in the process of becoming good members of their family, society and humanity as a whole (Akdere et al., 2006). More specifically, it focuses on advancing individual development, improving the understanding in society and its rules and transmitting knowledge (Halstead, 2004).

It is important to mention that education, from the Islamic perspective, involves not only a cognitive or emotive matter but also a practical one as learners ought to perform some actions in order to develop their capabilities (Bagheri \& Khosravi, 2006). In this respect, not only does coaching from the Islamic tradition provides entrepreneurs and leaders with theoretical principles, but it also draws their attention to the importance of basing coaching activities on practical wisdom. It should be noted that wisdom in Islam refers to the ability to make correct judgements and appropriate decisions; that act is to maximise beneficial results through doing what is best in any given situation (Khan, 2017).

As for the forms of coaching and other educational models in the early stages of Islam, three particular methods are commonly used with adult learners. These methods have left their imprint on current teaching and learning practices within business organisations and teaching institutions. The first form, the communication and discursive approach interact in nature. Its guidelines can be found in Quran, "Call to the way of your Lord with wisdom and beautiful preaching and argue with them with that which is best" (16:125). As for the parts of this form, Alam and Muzahid (2006) stated that the following methods are included. First, the wisdom application which refers to the use of instruction materials that are suitable to learners age, qualifications and experience; second, the beautiful preaching application which refers to the use of logic while instructing and adapting language; and finally, the application of the best 
possible way of arguing in interacting with learners through being patient and caring. In this regard, Muhammad (P.B.U.H) adopted various techniques such as storytelling which share moral values from meaningful stories from the past and indirect instruction which allowed the entire audience to take the benefit from a given topic without embarrassing any individual.

The second form, halaqa or the circle, begins initially as a group of students in a mosque, adopted over centuries and has taken different forms in dealing with diverse content. It has contributed to the appearance of structured institutions of higher learning (Stanton, 1990). The halaqa is an informal teaching and learning approach, a study group in which adult learners come together in semi-circles in front of an instructor. This educational method facilitates collaborative discussions and interactions between learners.

The third form is known as the tentative nomination consists of nominating people with high competence to certain positions to test their ability to assume various responsibilities and tasks. It also implies that their attitude will be closely observed. When they do a job well, they are promoted; however, if they fail, they will be dismissed as the second Caliph Omar did concerning one of his subordinates (Ali \& Weir, 2005). This form seems the same as on-thejob training, probation and temporary assignment strategies and techniques common to the modern-day workplace context.

\section{Islamic Business Coaching}

In terms of coaching, the literature has indicated that the concepts and practices of business coaching based on religion and spirituality are fundamentally different from conventional secular coaching. A fundamental difference between Islamic and conventional business coaching is that the majority of Muslim coaches use Qur'anic and the Prophetic saying in their approach to supporting the clients in obtaining God-perceived goals. Meanwhile, Islamic business coaches adhere to the rudimentary principles of conventional coaching, which are not contrary to the principle of Islam, such as asking powerful questions and attentive listening. Another is that the highest goal of IBC is seeking the blessings of God, which are not merely material profit. Unlike conventional coaching, the average emphasis is on the coachee's agenda and material goal achievement.

In the context of Christian coaching, Webb (2007) concludes that coaches who integrate their Christian beliefs, values, and worldview with coaching practices are better equipped to assist their coachees. When it is applied in IBC, those basic coaching principles, which are in keeping with Islamic beliefs, might reinforce coaching values and skills. Islamic business coaches should study the principles of Islamic worldview and Islamic business jurisprudence with regard to coaching from an Islamic framework. Also, both conventional and IBC impact on small businesses' performance is highly indicated, but conventional business coaching orientations indicate worldly needs. IBC orientation is part of non-particular worship (Yusanto \& Widjajakusuma, 2002).

Religion and spirituality have important roles in changing attitudes and behaviour. In order to support the change in the long-term, Covey (1989) incorporates three important factors supporting the internal changes, the awareness, desire and skill. Business coaching, which touches on basic values and paradigms of thinking has a huge impact on changes. Change from within is a change of habits and behaviours that have been repeated for some time. It is important to pinpoint that business coaching in Islam with its inherent practical wisdom unequivocally appeals to both faith and reason, hence contributing to making business coaching systems in Islamic societies more relevant and meaningful. Based on this literature, religious 
jurisprudence principles should be applied in business, capital and debt interest-free, the awareness of self-change, be harmonious with one another, straightforwardness, responsibility, truthfulness, with equity representing religion and spiritual values. Nonetheless, to determine values in IBC, there is a need to investigate coaches who are experts in this field.

Islamic business coaching is interpreted as a process of mentoring, training, consulting, and facilitating in business with comprehensive awareness and understanding of doing business in the Islamic principle, in terms of transactions, employment constructs, business cooperation, and customer service to achieve business and self-goals in world life and hereafter. Although there is a definition of Islamic business coaching based on literature, there is no evidence in Indonesia Islamic master coaches' perspective.

\section{Research Methodology}

This study explores, examines and describes the philosophical meanings of Islamic business coaching based on the understanding of Islamic business coaches in Indonesia and associated literature. It is a qualitative study that examines phenomena that occur in society. The primary data is collected from the Indonesian Islamic business coached and published academic literature (Singleton et al., 1988).

The research is conducted across several stages. The preliminary study phase begins with a review of the literature to identify the research gap. This is followed by the preparation phase in which we articulate the problems and objectives of this study, along with the appropriate research instruments consisting of preparing interview guides, selection of research subjects that fit the criteria of 5 coaches of Islamic business coaching, methods of gathering information with in-depth interviews and field notes. In the implementation stage, we collect information in accordance with the interview guide via in-depth interviews with 5 Islamic master business coaches in Indonesia. In the coding stage, the results of the interviews are recorded in writing. This is followed by the verification stage by sharing the recorded notes with the interviewees to check their validity. This is a continuous process to ensure robust results. The final phase in data analysis using content analysis to find definitions, philosophical meanings, and characteristics of Islamic business coaching.

\section{Result and Discussion}

\section{Islamic Business Coaching from Coaches' Perspective}

Based on the interview with the first informant, he explained that coaching is not only a subset of consultation, but also training and facilitation, mentoring, and supervision. He described it with the Venn diagram below:

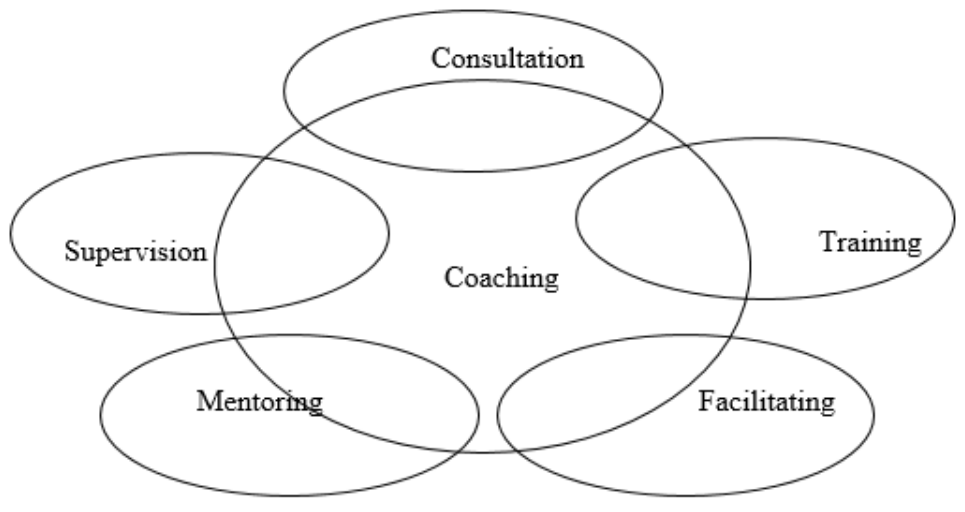




\section{Figure 1: Venn Diagram of Coaching}

Source: adopted from informant \#1

A consultant is a person who is trying to help the client to solve the problems with indirect influence and collaborative relationship (Block, 1999). As a subset of consultation, coaching provides consultancy services by establishing a collaborative relationship with experts in facilitating learning and goal attainment (Greene and Grant, 2003). Training is the process of imparting knowledge to a group for a general or specific purpose (Thompson \& Bale, 2006). A fundamental difference between 'training' and 'coaching' is that coaching personally determines kind of the best work personally. Coaches help each client to be a more effective person and business leader (McGovern et al., 2001).

The term 'facilitation' is used to describe any activity that is given, should be designing and run successfully, carry out productive and impartial meetings, develop team and group that allows change, and be concerned with decisions and how they are (Bacal, 2003). Although sometimes coaching is facilitation, there are some differences. Facilitation skills means working with groups and coaching means working for change which both on an organisational and an individual bases, enabling growth and change which are essential in team development (Zeus \& Skiffington, 2000). Meanwhile, mentoring is the directive sharing of wisdom and experiences with the client. The client listens and absorbs what has been told. Coaching is nondirective, where both the coach and the client jointly participate in an engagement. One of the coaching success parameters is how much the coach can elicit from the client (Heah, 2009).

Supervision refers to helping and educating professionals (van Kessel, 2007). Coaching is as a form of supervision, but coaching can also be education and learning through pointers, observations and feedback. Cox et al. (2014) studied various fields of coaching for instance, Attention Deficit Hyperactivity Disorder (ADHD) coaching, sports coaching, career coaching, financial coaching, spiritual coaching, Christian coaching, homework coaching, health and wellness coaching, life coaching, executive coaching, relationship coaching, and business coaching.

To sum up, coaching is the process of facilitating, consulting, mentoring, training and supervising to support the coachee (learner) in achieving a specific personal or professional goal by capitalising on his/her potential. On the other word, the term 'coaching' is used to describe a structured and continuous process of facilitating, consulting, mentoring, training and supervising to help the client reach meaningful and vital objectives as well as optimise his potential.

Based on the definitions of coaching, we conclude that business coaching is the process used to improve the coachees' business. The third informant mentioned that a business coach will help guide the business owner in developing their business by helping to explain their business vision and how it fits their personal goals. The second informant said that adjusting the business vision with the personal goals of the business owner is a step that is often overlooked by most business coaching since they only tend to focus on business goals. By doing so, it means they completely ignore the purpose of the business owner.

The fourth and fifth informants explained that business owners who take part in business coaching try to understand why achieving business growth goals are important to them personally and their impact on their lives. They are the principal determiners who determine the speed and enthusiasm in achieving the specified goals. If business owners do not have their 
dreams, goals, and plans for themselves, there will be no strong reason for the urgency to achieve their business goals (Mcguinness, 2008).

After clarifying where business owners want to run their business, according to the first and the fifth informants, business coaching will help the client to strategise and prioritise what goals and strategies are needed to help move the business closer to its goals. Business coaches will meet business owners regularly, weekly or monthly, to keep them on the commitment path made during the previous coaching session (Mcguinness, 2008).

\section{The Characteristics of Islamic Business Coaching}

The characteristics of Islamic business coaching can be seen from Islamic religiosity and its principles in the role of the coach, business coaching session focus, the result of business coaching and its satisfaction.

\section{Islamic Business Coach's Role}

Based on interviews about the role of the coach with five master coaches in IBC, it can be described that the key elements that underpin the role of the Islamic business coach are being effective listeners and sounding boards for small businesses practitioners. The indicators are giving the clients feedback on their ideas and opinions, very open approaching, promoting honest business, and sustainable relationships with you in business activities. As a listener, the coach shows empathy to your problem, becomes a good listener, provide coachees with knowledge, and listens attentively to the client's business experience.

While Ellinger et al. (2008) found that inhibiting coaching behaviour included directive, controlling, and dictatorial styles, several employers respecting a no-nonsense approach and direct feedback from business coaches. In contrast, other entrepreneurs prefer the consultative and facilitative styles provided by empathetic and non-judgemental business coaches but are involved in questions that provoke thought (Creane, 2006).

As an adviser, the coach assists me to state the commitment, to advise clients' problems, analysis coachees' problem, becoming coachees mentor. Business coaches are involved for a variety of reasons including increasing awareness of entrepreneurs, and recognition of the loneliness and alienation of positions, and the need to get advice from others (Cooper \& Quick, 2003).

The second informant said that as a spiritual motivator, the coach encourages them in spirituality, motivates them in businesses transaction based on the strengthening of spirituality, advises them on practising business ethics, and becoming passionate for a more meaningful life. Other employers seek business coaches for their skills, knowledge, and ability to act as network advisers, advisers and facilitators. Small businesses want the opportunity to learn from experienced business coaches especially spirituality who enhance the skills and knowledge of entrepreneurs, helping them to develop into their role as leading companies with strength of spirituality (Gibbons, 2000).

Overall, business coaches who are able to direct them to be closer to God, adapt to Islamic personalities and styles that best suit small business practitioners seem to be most effective (Ross et al., 2018). In addition, business coaches who are able to work with employers in matters relating to improving company performance, and providing spirituality support are highly valued by employers (Garcia-Zamor, 2003). 


\section{Focus of Islamic Business Coaching Session}

The fourth and fifth informants explained IBC session focus is the current focus of Islamic business coaches during sessions that contribute to the performance of self and the company. This entails strategic management, stakeholder management, organisation, business skill, Islamic business coaching value, and business ethics. The element of strategic management consists of the company's vision and mission, business goals, business strategy, and strategizing business plan. This explanation is similar to Blackburn, Hart \& Wainwright (2013), and Starman (2007). Stakeholder management indicators are the personal performance, customer satisfaction, labour performance, and stakeholder involvement (Gaskell et al., 2011). The indicator of the organisation is leadership development, character building, organisational culture, and organisational transformation. Business skill indicators are how to increase sales, customer services satisfaction, financial management, and cost efficiency. The element of Islamic business coaching value are Islamic rule in a business transaction, raising capital, labour construct, and customer relations (Hassi, 2012). The indicators of business ethics are truthfulness, social responsibility, respect for humanity, and legal compliance (Passmore \& Mortimer, 2011; Spiller, 2000).

The results of this study support Clegg et al. (2003) and Leonard \& Swap (2005) who stated that business coaching is a semi-structured process, focused on goals based on collaborative relationships and is very effective when done based on practical experience of coaching business. Coachees positively look at structured programmes that include training and business coaching. A coach works collaboratively with coachees to focus on their needs in learning as an effort to achieve their life goals and company performance (Gibb, 2009).

\section{Business Coaching Results}

The coaches of Islamic business coaching argued that the result of business coaches acquire skills in strategic management, stakeholder management, organisation, business skill, Islamic value in business coaching, and business ethics. In strategic management, the coachees are able to achieve their objective/goals, make a better, action plan, have a master plan. Their statements are supported by Cox et al. (2009), Vidal-Salazar, Ferrón-Vílchez \& Cordón-Pozo (2012). While, in stakeholder management, they have the ability to make better decisions, have more ideas/options to deal with issues, and encourage employees to achieve high performance (Fillery-Travis \& Passmore, 2011; Raven \& Le, 2015).

In organisations, the coachees support better leadership development, build a better character, and reform a better organisational culture (Tichy, 2002; Vries, M. F., Korotov \& FloreantTreacy, 2007). They advance business skills, increase their sales and revenue, service the customer in a better way, and practice cost efficiency (Wu, 2009). They also support Shari'ah compliant business transactions, raise Shari'ah compliant capital, and make customer relations Shari'ah compliant (Hassi, 2012; Rulindo \& Mardhatillah, 2007). In business ethics, they cultivate a more positive attitude towards life, have a more peaceful mind, and be more obedient in the law (Passmore \& Mortimer, 2011).

\section{Conclusion}

The definition of business coaching from the perspective of Indonesian Islamic coaches is slightly different from the common definition. The result of this study shows that the method of business coaching in Indonesia is a combination of methods, including training, mentoring, supervising, consulting, and facilitating. Thus, they interpret Islamic business coaching as a business coaching without ignoring the principle of Islamic law, spirituality and morality in business and self-development. 
The characteristics of Islamic business coaching in Indonesia were summarised as follows: (1) Master coaches in Islamic business coaching serve as a sounding board, listener, adviser, and spiritual motivator. The prominent characteristics in the Islamic business coach's role are spiritual motivator consisting of encouraging spirituality, spiritual motivating on business, advice, and passionate for a meaningful life. These prominent characteristics were significant in Islamic business coaching but not significant in conventional business coaching; (2) In the focus of business coaching session and result after getting business coaching, the prominent characteristics of Islamic business coaching is Islamic value in business coaching. It is represented by following Islamic rules in business transactions, raising capital, labour constructs, and customer relations.

\section{Limitations and Future Research}

The principal limitation of this study is that it uses a qualitative approach while generalising the result for Indonesia requires a quantitative approach. Nevertheless, the qualitative study could prove valuable in understanding the definition and characteristics of IBC. This was done by recording as many as five interviews, which could then be transcribed and analysed. The transcripts were inter-judged by a small panel of trained researchers working with a codebook developed by the authors. Content analysis research is time-consuming but was worth the effort. Further research could use a quantitative approach to confirm this result.

\section{References}

Akdere M, Darlene Russ-Eft, \& Natalie Eft. (2006). The Islamic Worldview of Adult Learning in the Workplace: Surrendering to God. Advances in Developing Human Resources, 8(3), 355-363. https://doi.org/10.1177/1523422306288428

Alam, K. U. A., \& Muzahid, M. A. U. (2009). Informal Islamic Education and its Role in Human Resource Development in Society: A Theoretical Evaluation. IIUC Studies, 3, 83-92. https://doi.org/10.3329/iiucs.v3i0.2667

Ali, A. J., \& Weir, D. (2005). Islamic Perspectives on Management and Organization. 2(3), 410-415. Cheltenham: Edward Elgar Publisher.

Arifin, S. (2015). Syariah Business Coach. Retrieved November 2, 2016, from http://sbcglobal.co.id/who-whe-are-syariah-business-coach.

Audet, J., \& Couteret, P. (2012). Coaching the Entrepreneur: Features and Success Factors. Journal of Small Business and Enterprise Development, 19(3), 515-531. https://doi.org/10.1108/14626001211250207

Audretsch, D. B., Bönte, W., \& Tamvada, J. P. (2013). Religion, social class, and entrepreneurial choice. Journal of Business Venturing, 28(6), 774-789.

Bacal, R. (2003). The Manager's Guide to Performance Reviews. McGraw-Hill Professional. Retrieved from http://site.ebrary.com/lib/ncent/docDetail.action?docID=10051505\&p00\%5Cnhttp://s cholar.google.com/scholar?hl=en\&btnG=Search\&q=intitle:Manager's+guide+to+perf ormance+reviews \#0

Bacon, T. R., \& Spear, K. I. (2003). Adaptive Coaching: The Art and Practice of a ClientCentered Approach to Performance Improvement. Palo Alto, CA: Davis-Black. 67-85.

Bagheri, K., \& Khosravi, Z. (2006). The Islamic Concept of Education Reconsidered. American Journal of Islamic Social Sciences, 23(4), 88-103.

Bartley, S. M. (2011). A Phenomenological Study of Christian Coaching. ProQuest Dissertations and Theses. Regent University. Retrieved from http://ezproxy.liberty.edu/login?url=http://search.proquest.com/docview/917244467?a ccountid=12085\%5Cnhttp://rx9vh3hy4r.search.serialssolutions.com/?ctx_ver=Z39.88 
-2004\&ctx_enc=info:ofi/enc:UTF-

8\&rfr_id=info:sid/Religion+Database\&rft_val_fmt=info:ofi/fmt:k

Bellu Renato R., P. F. (2004). Religiosity and entrepreneurial behaviour: An exploratory study. Entrepreneurship and Innovation. 5(3), 12-23. https://doi.org/10.5367/0000000041513411.

Bennis \& O'Toole, J., W. G. (2005). How Business Schools Lost Their Way. Harvard Business Review, 83(5), 96-104.

Blackburn, R. A., Hart, M., \& Wainwright, T. (2013). Small Business Performance: Business, Strategy and Owner Manager Characteristics. Journal of Small Business and Enterprise Development, 20(1), 8-27. https://doi.org/10.1108/14626001311298394

Blackman, A. (2006). Factors That Contribute to The Effectiveness of Business. Coaching: The Coachees Perspective. The Cambridge Business Review, 5, 1(2), 98-104.

Block, P. (1999). Flawless Consulting: A Guide To Getting Your Expertise Used. San Francisco: Pfeiffer \& Co. 10-20.

Branine, M., \& Pollard, D. (2006). Human Resource Management With Islamic Management Principles: A Dialectic For A Reverse Diffusion In Management. Personnel Review, 39(6), 712-727. https://doi.org/10.1108/00483481011075576

Choi, H. (2010). Religious institutions and ethnic entrepreneurship: The korean ethnic church as a small business incubator. Economic Development Quarterly, 24(4), 372-383. https://doi.org/ 10.1177/0891242410375426

Clegg, S. R., Rhodes, C., Kornberger, M., \& Stilin, R. (2005). Business coaching: Challenges for an emerging industry. Industrial and Commercial Training, 37(5), 218-223. https://doi.org/10.1108/00197850510609630

Collins R, G. (2001). Christian Coaching: Help Others Turn Potential Into Reality (2n ed). Colorado Spring, CO: NavPress. 10-20.

Covey, S. R. (1989). The 7 habits of highly effective people. New York: Simon and Schuster.

Cox, E., Bachkirova, T., \& Clutterbuck, D. (2009). The Complete Handbook of Coaching (2nd ed.). London: Sage. Retrieved from papers2://publication/uuid/0B92C583-355E-40F39552-B07BBBEA91E7

Crompton, B. M. (2012a). The Effect of Business Coaching and Mentoring on Small-ToMedium Enterprise Performance and Growth. RMIT University. 10-20.

Crompton, B. M. (2012b). The Effect of Business Coaching and Mentoring on Small-ToMedium Enterprises Performance and Growth. RMIT University. 10-20.

Crompton, B. M., Smyrnios, K. X., \& Bi, R. (2012). Measuring the influence of business coaching on fast-growth firms. Small Enterprise Research. 19(1). 16-31. https://doi.org/10.5172/ser.2012.19.1.16

Dana, L. P. (2009). Religion as an explanatory variable for entrepreneurship. The International Journal of Entrepreneurship and Innovation, 10(2), 87-99. https://doi.org/10.5367/000000009788161280

Din Ahmed, M. U. (1968). Muslim Education and the Scholars' Social Status up to the 5th Century Muslim Era (11th Century Christian Era). Zurich: Verlag Der Islam. 10-20.

Dodd, S.D., G. G. (2007). The Interrelationships Between Entrepreneurship and Religion. Florida. 10-20.

Drakopoulou Dodd, S. Seaman, P. T. (1998). Religion and Enterprise: An Introductory Exploration. Entrepreneurship: Theory \& Practice, 23, 71-86.

Essers, C. \& Benschop, Y. (2009). Muslim Business Women Doing Boundary Work: The Negotiation of Islam, Gender and Ethnicity within Entrepreneurial Contexts. Human Relations, 62(3), 403-423. https://doi.org/10.1177/0018726708101042 
Evers, W., Brouwers, A., \& Tomic, W. (2006). A Quasi-Experimental Study on Management Coaching Effectiveness. Consulting Psychology Journal: Practice and Research, 58(3), 174-182. https://doi.org/10.1037/1065-9293.58.3.174

Grine, F. (2014). Empowering Muslim Women Though Executive Coaching \& Mentoring. International Journal of Nusantara Islam, 2(1), 53-70. https://doi.org/10.15575/ijni.v2i1.48

Fatoohi, L. (2009). Jihad in the Qur'an: The Truth from the Source. Birmingham, UK: Luna Plena Publishing. 10-20.

Fillery-Travis, A., \& Passmore, J. (2011). A critical review of executive coaching research: a decade of progress and what's to come. Coaching: An International Journal of Theory, Research and Practice, 4(2), 70-88. https://doi.org/http://dx.doi.org/10.1080/17521882.2011.596484

Galbraith, C. S. \& Galbraith, D. M. (2007). An empirical note on entrepreneurial activity, intrinsic religiosity and economic growth. Journal of Enterprising Communities, 1(2), 188-201.

Garcia-Zamor, J. (2003). Workplace Spirituality and Organizational Performance. Public Administration Review, 63(3), 355-363. https://doi.org/10.1111/1540-6210.00295

Gaskell, C., Logan, J., \& Nicholls, L. (2011). Igniting Business Performance Through Transformational Coaching. Strategic HR Review, 11(1), 18-24. https://doi.org/10.1108/14754391211186278

Gibbons, P. (2000). Spirituality at Work: Definitions, Measures, Assumptions, and Validity Claims. Work and Spirit: A Reader of New Spiritual Paradigms for Organizations, 111131.

Goldsmith, M. (2000). Are You Ready? Harvard Business Press. 10-20.

Gotsis, G. \& Kortezi, Z. (2009). The impact of greek orthodoxy on entrepreneurship: A theoretical framework. Journal of Enterprising Communities, 3(2), 152-157. https://doi.org/10.1108/17506200910960851

Grant, A. (2006). Workplace And Executive Coaching: A Bibliography From Scholarly Business Literature. In D. R. Stober \& A. M. Grant (Eds.), Evidence-Based Coaching Handbook (pp. 268-279). Hoboken, NJ: John Wiley \& Sons. 10-20.

Greene, J., \& Grant, A. M. (2003). Solution-Focused Coaching: Managing People In A Complex World. Harlow: Pearson Education Limited. 10-20.

Halstead, J. M. (2004). An Islamic Concept of Education. Comparative Education, 40(4), $517-$ 529. https://doi.org/10.1080/0305006042000284510

Hashim, J. (2010). Human Resource Management Practices On Organizational Commitment: The Islamic Perspective. Personnel Review, 39(6), 789-799. https://doi.org/10.1108/00483481011075611

Hassi, A. (2012). Islamic Perspectives on Training and Professional Development. Journal of Management Development, 31(10), 1035-1045. https://doi.org/10.1108/02621711211281816

Heah, M. (2009). Dialogue With The Coach: 100 cases, 100 strategies, 100 solutions. MPH Group Publishing Sdn Bhd. 10-20.

Homan, M., \& Miller, L. J. (2008). Coaching in Organizations: Best Coaching Practices from The Ken Blanchard Companies. John Wiley \& Sons, Inc. 10-20.

Hsieh, H.-F., \& Shannon, S. E. (2005). Three Approaches to Qualitative Content Analysis. Qualitative Health Research, 15(9), 1277-1288. https://doi.org/10.1177/1049732305276687

Ives, Y. (2008). What is ' Coaching '? An Exploration of Conflicting Paradigms. International Journal, $6(2)$, $100-113$. https://doi.org/http://ijebcm.brookes.ac.uk/documents/vol06issue2-paper-08.pdf 
Joel A. Ryman, C. A. T. (2007). The modern Weberian thesis: a short review of the literature. Journal of Enterprising Communities, 1(2), 175-187.

Khan, S. (2017). The Exercise of Hikmah.. Wisdom. Retrieved November 1, 2017, from https://www.islamicity.org/3092/the-exercise-of-hikmah-wisdom/

Koenig HG, McCullough ME, L. D. (2001). Religion and Health. New York: Oxford University Press. 10-20.

Leedham, M. (2005). The Coaching Scorecard: a holistic approach to evaluating the benefits of business coaching. International Journal of Evidence. Based Coaching and Mentoring, 3(2), 30. Retrieved from http://www.desafiobc.cl/wpcontent/uploads/vol03issue2-paper-03.pdf

Leonard, B., \& Biberman, J. (2007). Utilizing Multi-Dimentionality in The Workplace: a MetaStudy. The University of Scanton, Pennsylvania, USA. 10-20.

Life Coaching Institute. (2012). About Life Coaching. Retrieved December 5, 2015, from https://www.lcia.com.au/about-life-coaching.aspx

McCluskey, C. (2008). Professional Christian Coaching: How Christian? How Professional? Journal of Christian Coaching, 7(9). 10-20.

McCormick, D. W. (1994). Spirituality and Management. Journal of Managerial Psychology, 9(6), 5-8. https://doi.org/10.1108/02683949410070142

McGovern, J., Lindemann, M., Vergara, M., Murphy, S., Barker, L., \& Warrenfeltz, R. (2001). Maximizing the Impact of Executive Coaching: Behavioural Change, Organizational Outcomes And Return On Investment. The Manchester Review. 10-20.

Mcguinness, M. (2008). Creative Management for Crative Teams: Business Coaching and Creative Business. Wishfulthinking.co.uk. London: Creative Commons licence. 10-20.

McLennan Tajiri, N. A. (2009). Attentiveness To God: Contemplative Presence In Spiritual Direction. Institute Of Transpersonal Psychology. 10-20.

Milliman, J., Czaplewski, A. J., \& Ferguson, J. (2003). Workplace Spirituality And Employee Work Attitudes: An Exploratory Empirical Assessment. Journal of Organizational Change Management, 16(4), 426-447. https://doi.org/10.1108/09534810310484172

Mumby-Croft, R., \& Brown, R. B. (2005). Management Development in SMEs: Practical Insights From A University Programme. Journal of Management Development, 24(50), 670-682. https://doi.org/10.1111/j.1468-2370.2006.00125.x

Neck, C. P., \& Milliman, J. F. (1994). Thought Self-Leadership: Finding Spiritual Fulfilment In Organizational Life. Journal of Managerial Psychology, 9(6), 9-16. https://doi.org/10.1108/02683949410070151

Neubert, M. J. \& Beard, A. (2013). Entrepreneurs feel closer to god than the rest of us do. Harvard Business Review, 91(10), 32-33.

Newell, P. (2009). What is the Biblical basis of coaching? Coach Approach Ministries (CAM). 10-20.

Passmore, J., \& Mortimer, L. (2011). Ethics in coaching. In Advanced executive coaching. San Fransisco: Wiley. 10-20.

Raven, P., \& Le, Q. V. (2015). Teaching business skills to women: Impact of business training on women's microenterprise owners in vietnam. International Journal of Entrepreneurial Behaviour and Research, 21(4), 622-641. https://doi.org/10.1108/IJEBR-06-2014-0099

Rock, D., \& Page, L. J. (2009). Coaching with the Brain in Mind: Foundations for Practice. John Wiley \& Sons, Inc. 10-20.

Ross, A., Brock, V. G., Grodzki, L., Langner, H., Keller, J., Margariti, M., ... Sabatine, J. M. (2018). Coaching and Spirituality: A Mutually Resourceful Relationship. In S. S. English Janice Manzi; Brownell, Philip (Ed.), Professional Coaching: Principles and 
Practice (1st ed.). New York: Springer Publishing Company. https://doi.org/10.1891/9780826180094

Rulindo, R., \& Mardhatillah, A. (2007). Spirituality , Religiosity and Economic Performances of Muslim Micro- Entrepreneurs. 8th International Conference On Management From Islamic Perspective, International Islamic University Malaysia And Islamic Research And Training Institute ( IRTI ), Kuala Lumpur, 1-13. https://doi.org/10.1016/j.ijcard.2017.03.069

Rulindo, R., \& Mardhatillah, A. (2011). Spirituality, religiosity and economic performances of Muslim micro-entrepreneurs. 8th International Conference on Islamic Economics and Finance, 1-13.

Sayeda Habib. (2012). Life Coaching for Muslims: Discover the Best in You! Kube Publishing. 10-20.

Sexton, D. L., Upton, N. B., Wacholtz, L. E., \& McDougall, P. P. (1997). Learning Needs Of Growth-Oriented Entrepreneurs. Journal of Business Venturing. 10-20.

Spiller, R. (2000). Ethical Business and Investment: A Model for Business and Society. Journal of Business Ethics, 27(1/2), 149-160. https://doi.org/10.1023/A:1006445915026

Stanton, C. M. (1990). Higher Learning in Islam. Rowman \& Littlefield Publishers. 10-20.

Stark, R., \& Bainbridge, W. (1985). The Future of Religion: Secularization, Revival, and Cult Formation. Berkeley: University of California Press. 10-20.

Starman, J. (2007). The Impact of Executive Coaching on Job Performance From The Perspective of Executive Woman. Capella University. Capella University. 10-20.

Stein, J. C. (2003). Agency, Information and Corporate Investment. In The Economics of Finance. 67-89.

Swanson, R., \& Holton, E. (1997). Human Resource Development: Research Handbook Linking Research And Practice. San Francisco: Berrett-Koehler. 10-20.

Thompson, J., \& Bale, R. M. (2006). Effective Entrepreneur Enabling - Increasing the Effectiveness of Advising, Coaching and Mentoring Support. Institute for Smail Business \& Entrepreneurship, (November), 1-12.

Tichy, N. M. (2002). The leadership engine: How winning companies build leaders at every level. New York: HarperCollins Publishers. 10-20.

Valliere, D. (2008). Exploring buddhist influence on the entrepreneurial decision. International Journal of Entrepreneurial Behavior and Research, 14(3), 172-191. https://doi.org/10.1108/13552550810874682

van Kessel, L. (2007). Coaching, a field for professional supervisors? Ljetopis Socijalnog Rada, 14(2), 387-432.

Vidal-Salazar, M. D., Ferrón-Vílchez, V., \& Cordón-Pozo, E. (2012). Coaching: An effective practice for business competitiveness. Competitiveness Review, 22(5), 423-433. https://doi.org/10.1108/10595421211266302

Vries, K. de, M. F., Korotov, K., \& Floreant-Treacy, E. (2007). Coach and couch: The psychology of making better leaders. New York: Palgrave Macmillan. 10-20.

Webb, K. E. (2007). Why Faith-Based Professional Coach Training? Retrieved November 1, 2015, from http://www.creativeresultsmanagement.com/whycoaching.

Weber, M. (1930). The Protestant Ethic and the Spirit of Capitalism. London: Routledge. 3335.

Whiteside, S. T. (2013). Impact of Executive Coaching on Small Business and Franchisees. Fielding Graduate University. 21-31.

Whitmore, J. (1992). Coaching for performance. London: Nicholas Brealey. 10-20.

Williams, P., \& Davis, D. C. (2007). Therapist as Life Coach: An Introduction for Counselors and Other Helping Professionals, Revised and Expanded. W.W. Norton. 10-20. 
Wright, M. (2004). Hospice Care and Models of Spirituality. European Journal of Palliative Care, $75-78$.

Wu, D. (2009). Measuring Performance in Small and Medium Enterprises in the Information \& Communication Technology Industries. RMIT University. 32-35.

Yusanto, M. I., \& Widjajakusuma, M. K. (2002). Menggagas Bisnis Islami (Initiated Islamic Business). Jakarta: Gema Insani Press.

Zeus, P., \& Skiffington, S. (2000). The Complete Guide To Coaching At Work. Australia: McGrall-Hill. 54-60. 